\title{
Correction: Association of smoking and right ventricular function in middle age: CARDIA study
}

Moreira HT, Armstrong AC, Nwabuo CC, et al. Association of smoking and right ventricular function in middle age: CARDIA study. Open Heart 2020;7:e001270.

In the end matter, 'Provenance and peer review' statement has been correctly updated as 'Not commissioned; externally peer reviewed'.

Open access This is an open access article distributed in accordance with the Creative Commons Attribution 4.0 Unported (CC BY 4.0) license, which permits others to copy, redistribute, remix, transform and build upon this work for any purpose, provided the original work is properly cited, a link to the licence is given, and indication of whether changes were made. See: https:// creativecommons.org/licenses/by/4.0/.

(C) Author(s) (or their employer(s)) 2020. Re-use permitted under CC BY. Published by BMJ.

Open Heart 2020;7:e001270corr1. doi:10.1136/openhrt-2020-001270corr1

(D) Check for updates 